\title{
Closure of Berkeley nuclear plant signals decline of the Magnox
}

\section{London}

THE closure of Britain's first strictly commercial nuclear power station was announced last week, following a critical safety review last year by the Nuclear Installations Inspectorate (NII,-see Nature 332, 772; 1988). The Central Electricity Generating Board (CEGB), which runs the station, has decided that the costs of implementing the safety requirements are too great.

The station, at Berkeley in Gloucestershire, was commissioned in 1962, at the same time as another at Bradwell in Essex. Both were subject to long-term safety reviews when the CEGB indicated it wished to keep them operating beyond their expected lifetime of $20-25$ years. For Berkeley, the NII listed 17 key requirements that $\mathrm{CEGB}$ would have to
NII says it expects that work similar to that required on Berkeley and Bradwell will be necessary on the other Magnox reactors. Eddy Ryder, chief of the inspectorate, says there are common problems because of ageing and tightened safety standards. But the future of these reactors will depend on whether CEGB and the separate Scottish utilities decide it is economic to carry out the work. Exactly how decommissioning will be carried out at Berkeley, and the cost, is not certain, but something will have been learned from the dismantling of a reactor at Sellafield in Cumbria.

One reactor at Berkeley will be shut in October, the other next March. CEGB expects that half of the 532 staff will be occupied for five years in removing fuel from the reactor and its cooling ponds.

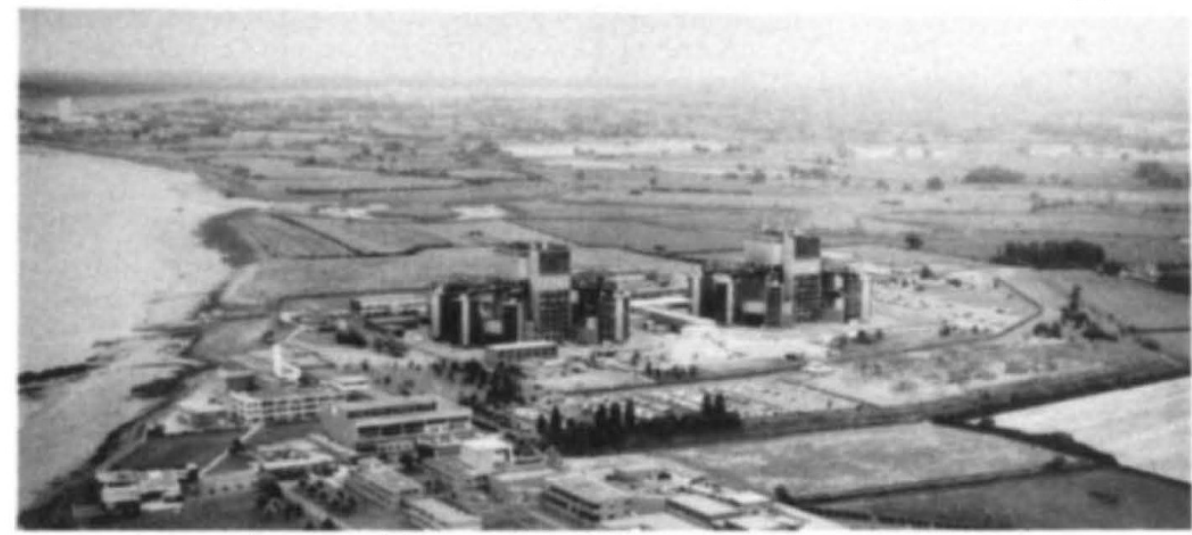

Industrial archaeology: one of the options for Berkeley is conversion into a museum.

meet in order to run the station until 1992; the cost of the work was estimated to be around $£ 4$ million.

The verdict on Bradwell was similar. Improvements are going ahead at Bradwell, where ways have been found of making them without shutting down the reactors for long periods. But at Berkeley, where a series of technical problems over the past five years has made the station's operating costs twice as high as the average of the CEGB's other seven Magnox stations, the plant will be closed.

Berkeley has been giving the CEGB problems for some time: since 1983 it has been necessary to shut down its reactors for refuelling because of faults in the main crane used to service the reactor, while one out of eight coolant gas circuits on each of its two reactors is permanently closed and gas pressure reduced by 10 per cent. Total output is thus reduced from $276 \mathrm{MW}$ to $200 \mathrm{MW}$. All eight of CEGB's Magnox stations together provide half of Britain's nuclear electricity, itself 16 per cent of total generation last year.

The next safety report (on Hunterston $A$ in Scotland) is due in the autumn, but
Thereafter, it will take $5-7$ years to remove the external buildings, leaving only the sealed reactors. Stage three, dismantling the reactors, will be postponed for up to a century. The entire process is expected to cost around $£ 300$ million, compared with the $£ 450$ million set aside by CEGB. But, with privatization of the electricity supply industry imminent, it is not clear who will pay for the decommissioning of the CEGB's other seven Magnox reactors.

In what seems a bid to win over public opinion, CEGB is considering plans to turn Berkeley into a museum instead of returning it to a green-field site. CEGB says it is following with interest developments at Chinon, in France, where the same idea has been canvassed.

Christine McGourty - Another cloud hanging over Britain's nuclear industry is the disposal of radioactive waste. NIREX, the government's waste disposal agency, expects that 1.5 million $\mathrm{m}^{3}$ of low-level waste, such as discarded protective clothing, will be produced between now and 2030. But the one site now in use will hold only a third of

\section{Register pleases epidemiologists}

\section{London}

THE United Kingdom and Ireland are the only members of the European Community with no form of population register. Administrators and politicians in Britain have long avoided the issue, fearing public opposition. But in a report published last week, Philip Redfern, formerly of the government's Office of Population Censuses and Surveys, says they may not be able to do so much longer. With the removal of frontier controls and the free movement of people and trade, exchanges of personal data will increase and greater compatibility between national record systems will be necessary.

Redfern argues the benefits a register would bring to society, the government and to statisticians. And it would not affect people's privacy, he says, as a wide range of personal data is already held by public authorities.

But a lack of coordination between them leads to duplication and inconsistency. A centralized register would bring some order to this ramshackle system, says Redfern. It would put a brake on fraud, crime and illegal immigration and lead to a fairer society where duties were fairly shared and benefits and rights go to those entitled to them. A register would save the government money, he says, by reducing administrative costs and cutting losses from tax evasion and improperly paid benefits. Implementation of policies would also be easier: data would already exist on which to base a cancer screening programme, for example.

Christine McGourty

that. And for intermediate-level waste, such as irradiated fuel cladding and reactor components, NIREX has not yet found an acceptable means of disposal. By $2030,250,000 \mathrm{~m}^{3}$ will have accumulated At present it is stored where it is created. High-level waste is similarly in storage, pending a decision on disposal.

Last year NIREX circulated a discussion document outlining three possible options for disposal of low-and intermediate-level waste: a deep-mined cavity below land or an offshore cavity below the sea-bed reached either by a tunnel from the coast or by a drilling platform. Site proposals are expected later this year.

But plans for a deep disposal facility have already been set back; the local authority has refused planning permission to British Nuclear Fuels Ltd, which wanted to drill at Sellafield in a preliminary geological investigation. NIREX abandoned plans for a shallow dump over a year ago because of the strength of public opposition.

C.McG. 